\title{
Effect of intradialytic exercise on bone profile in hemodialysis patients
}

\author{
Howaida Abdelhameed Elshinnawy ${ }^{1}$, Ahmed Mohamed Bakr Bakr Mohamed ${ }^{1}$, Dina Abou Bakr Farrag ${ }^{2^{*}}$ and \\ Moustafa Abd Elnassier AbdElgawad
}

\begin{abstract}
Background: Chronic kidney disease increases the risk of fractures and altered bone and mineral metabolism. Exercise training could be a non-pharmacological therapeutic intervention. The aim of this work is to evaluate the effect of intradialytic exercise training on bone markers in hemodialysis (HD) patients.

Results: Forty adult patients on regular HD participated in the study. Twenty of which completed 3 months supervised intradialytic cycling exercise program and 20 served as controls. At baseline, there was no difference between both groups regarding age, sex, physical performance, and laboratory studies performed. After 3 months, the exercise group showed significant improvement in short performance battery test (SPBT) total score $(P<0.001)$ associated with significant decrease in serum parathormone $(P T H)(P=0.01)$ and increase in serum alkaline phosphatase (ALP) and bone specific alkaline phosphatase (BALP) $(P<0.05$ and $P<0.001$ respectively). Controls did not show similar change in SPBT or laboratory studies. There was no significant change in serum calcium or phosphorus in both groups. A significant positive correlation was observed between SPBT scores post-exercise and both BALP and ALP levels ( $r=0.432, P=0.01$ and $r=0.645, P<0.01$ respectively). Also, an inverse relation was observed between SPBT and PTH $(r=-0.503, P=0.01)$.
\end{abstract}

Conclusion: Intradialytic cycling exercise program resulted in significant increase in physical performance associated with decrease in serum PTH and increase in BALP and ALP in HD patients. This indicates the positive influence of exercise not only on physical performance in dialysis patients but also on bone metabolism.

Keywords: Intradialytic exercise, Bone-specific alkaline phosphatase, Bone biomarkers, PTH

\section{Background}

Chronic kidney disease mineral and bone disorder (CKD-MBD) is common among patients with chronic kidney disease (CKD) and contributes to the high incidence of fracture and cardiovascular mortality risk in these patients [1]. This systemic disorder CKD-MBD manifests by one or more of the following: abnormalities in serum calcium, phosphorus, parathyroid hormone (PTH), or vitamin $\mathrm{D}$, and also bone histological lesions marked by changes in bone turnover, mineralization, volume, growth, and the presence of extraosseous

\footnotetext{
*Correspondence: dinaaboubakr@yahoo.com

2Department of Physical Medicine, Rheumatology and Rehabilitation, Faculty of Medicine, Ain Shams University, Cairo, Egypt

Full list of author information is available at the end of the article
}

vascular or other soft tissue calcification [2]. Renal osteodystrophy (ROD) is the bone component of CKDMBD. Rate of bone turnover may be low, high, or normal. Also, rate of mineralization is either low or normal. Bone mass is physiologically linked to rate of change in bone remodeling [3].

Although the golden standard for diagnosis of CKDBMD is bone biopsy, this procedure is invasive and inconvenient for repetition [2]. According to Kidney Disease: Improving Global Outcomes KDIGO 2017 guidelines, bone turnover in these patients could be monitored using serum markers: bone specific alkaline phosphatase BALP and parathyroid hormone PTH [4].

Patients with end-stage renal disease (ESRD) are characterized by low levels of physical activity and 
continuous decline in physical function associated with increased risk of morbidities and mortalities [5, 6].

The effect of exercise on bone metabolism has been highlighted in healthy adults. Exercise has osteogenic effect on bone [7]. In CKD, few studies are available to support the positive effect of exercise on bone metabolism in these patients [8].

The aim of this work is to evaluate the effects of intradialytic exercise on bone markers in hemodialysis HD patients.

\section{Methods}

\section{Study design and participants}

This prospective case-control study included 40 patients with end stage renal disease on regular hemodialysis recruited from hemodialysis unit at Ain Shams University Hospital.

\section{Inclusion criteria}

All patients on HD 3 times/week for at least 6 months, age $\geq 18$ years, could walk unaided, fit for exercise by functional assessment using $6 \mathrm{~min}$ walk test [9], and hemoglobin level $\geq 10$

\section{Exclusion criteria}

Patients with other chronic illness, endocrinal, malignancy, liver disease, medications that could affect bone metabolism. Patients with any mechanical disorder or disability that prevented cycling, uncontrolled diabetes, uncontrolled hypertension, history suggestive of recent angina or cardiopulmonary disease. Acute infection, hyperkalemia, or hypokalemia

The study was performed in accordance with the Declaration of the Helsinki. It was approved by the Ethics Committee of Faculty of Medicine, Ain Shams University, approval number MS285/2020. Written informed consent was obtained from all the participants.

Patient volunteers fulfilling the inclusion criteria were equally stratified according to age and gender and divided into exercise group who participated in exercise program and control group who did not participate in exercise in any form. All patients were subjected to full history taking and complete clinical examination, including musculoskeletal and neurological examination.

\section{Anthropometric assessment}

Body mass index (BMI) was calculated as dry body weight $(\mathrm{kg})$ divided by the squared height (meter).

\section{Physical performance assessment}

1. Six-minute walk test was performed at baseline [9].

2. Short physical performance battery test (SPBT)
It included gait speed (usual time to walk $4 \mathrm{~m}$ ), five chair-stand test (time to rise from a chair and return to the seated position five times without using arms), and balance test (ability to stand with the feet together in the side-by-side, semi-tandem, and tandem positions). A score from 0 to 4 was assigned to performance on each task. Individuals received a score of 0 for each task they were unable to complete. Summing the three individual categorical scores, a summary performance score was created for each participant (range, 0-12), with higher scores indicating better lower body function [10].

\section{Laboratory assessment}

Blood samples were withdrawn early morning before dialysis at baseline and after 3 months of exercise training from each subject for complete blood picture, albumin, serum calcium and phosphorus, PTH, total ALP, and BSAP using enzyme-linked immunosorbent assay ELISA (Kit from Bioassay technology, Shanghai).

\section{Physical exercise program included}

Patients received education on importance of exercise and physical activity, how to monitor their physical exertion, and when to stop exercise.

Patients received supervised, intradialytic exercise sessions, three times per week, during the first $2 \mathrm{~h}$ of dialysis. Patients exercised on pedal trainer exercise bike. The exercise peddler was placed in front of hemodialysis chair, and patients were allowed to pedal freely while sitting upright. Precautions and progression were according to protocol recommended previously by Southern Albert Renal Program [11]. Each exercise session consisted of three basic phases:

a) Warming up part: 5-min light exercise

b) Main part: start with 10-min cycling in conditioning phase and gradual progression in the later phase up to 30-min cycling.

c) Final part (cooling down): 5 min of relaxation and breathing exercise.

The recommended intensity of exercise was within submaximal range which is $60-70 \%$ of the maximal HR. Intensity was monitored by Borg scale [12] starting at low-intensity exercise with rate of perceived exertion (RPE) of 7-9 and progressing to RPE of 12-13 (moderate or somewhat hard intensity) according to patient's tolerance.

During the exercise sessions, patients were monitored for heart rate, blood pressure, and signs of fatigue. Exercise was terminated in case of intense physical fatigue, chest pain, dizziness, pallor, tachycardia, hypotension, or hypertension. 
Reassessment of patients in both exercise and control group after 3 months included clinical, anthropometric, laboratory, and physical performance assessment.

\section{Statistical analysis}

Recorded data were analyzed using the statistical package for social sciences, version 20.0 (SPSS Inc., Chicago, IL, USA). Quantitative data were expressed as mean \pm standard deviation (SD). Qualitative data were expressed as frequency and percentage. Independent samples $t$-test of significance was used when comparing between two means. Mann-Whitney $U$ test was used for two-group comparisons in non-parametric data. Chi-square $\left(\chi^{2}\right)$ test of significance was used in order to compare proportions between qualitative parameters. Spearman's rank correlation coefficient $(r)$ was used to assess the degree of association between two sets of variables if one or both of them were skewed. The confidence interval was set to $95 \%$, and the margin of error accepted was set to $5 \%$. So, the probability $P$-value was considered significant as follows: $P$-value $\leq 0.05$ was considered significant, $P$-value $\leq 0.001$ was considered as highly significant, $P$-value $>0.05$ was considered insignificant.

\section{Results}

This study included 40 patients on hemodialysis. All patients in period of study continued regular HD sessions, 3 times/week. Patients were divided equally into exercise group $(n=20)$ and controls $(n=20)$. No difference was detected between patients and controls regarding baseline age, sex, and body mass index $(P>0.05)$. Physical performance levels measured using 6-min walk test and SPBT were comparable at baseline between both groups $(P>0.05)$ as seen in Table 1.

Also, no difference between groups was detected regarding baseline bone profile, hemoglobin $(\mathrm{Hgb})$, and albumin levels $(P>0.05)$ as seen in Table 1.

In this work, there was no difference between groups regarding percentage of patients with special habits like smoking and percentage of patients with HTN, dyslipidemia, and DM $(P>0.05)$. None of the patients suffered from chronic obstructive pulmonary or ischemic heart disease.

After completion of 3 months exercise program, the exercise group showed statistically significant increase in SPBT total score and its components, including balance, gait speed, and chair stands as seen in Table 2. However, the control group showed no significant change in SPBT as seen in Tables 3 and 4.

Table 1 Comparison between exercise and control group regarding baseline demographic data, physical performance scores and laboratory tests

\begin{tabular}{|c|c|c|c|c|c|}
\hline & Groups & Exercise $\mathrm{Gr}(n=20)$ & Control Gr $(n=20)$ & $t$-test & $P$-value \\
\hline Age (years) & $\begin{array}{l}\text { Mean } \pm S D \\
\text { Range }\end{array}$ & $\begin{array}{l}44.20 \pm 13.04 \\
22-61\end{array}$ & $\begin{array}{l}46.05 \pm 11.59 \\
22-65\end{array}$ & 0.474 & 0.638 \\
\hline Gender & $\begin{array}{l}\text { Females } \\
\text { Males }\end{array}$ & $\begin{array}{l}8(40.0 \%) \\
12(60.0 \%)\end{array}$ & $\begin{array}{l}6(30.0 \%) \\
14(70.0 \%)\end{array}$ & $x^{2}=0.440$ & 0.507 \\
\hline BMI $\left[\mathrm{Kg} / \mathrm{m}^{2}\right]$ & $\begin{array}{l}\text { Mean } \pm \text { SD } \\
\text { Range }\end{array}$ & $\begin{array}{l}26.40 \pm 2.87 \\
22-32\end{array}$ & $\begin{array}{l}27.00 \pm 3.09 \\
24-33\end{array}$ & 0.635 & 0.529 \\
\hline 6-min walk (m) & $\begin{array}{l}\text { Mean } \pm S D \\
\text { Range }\end{array}$ & $\begin{array}{l}361.00 \pm 12.94 \\
340-380\end{array}$ & $\begin{array}{l}358.50 \pm 13.68 \\
345-370\end{array}$ & 0.635 & 0.529 \\
\hline SPBT & $\begin{array}{l}\text { Mean } \pm S D \\
\text { Range }\end{array}$ & $\begin{array}{l}6.40 \pm 1.05 \\
5-8\end{array}$ & $\begin{array}{l}6.55 \pm 1.10 \\
5-8\end{array}$ & -0.442 & 0.661 \\
\hline HGB (g/dl) & $\begin{array}{l}\text { Mean } \pm S D \\
\text { Range }\end{array}$ & $\begin{array}{l}11.06 \pm 1.09 \\
10-14.2\end{array}$ & $\begin{array}{l}11.26 \pm 1.12 \\
10-13.7\end{array}$ & 0.000 & 1.000 \\
\hline Albumin (g/dl) & $\begin{array}{l}\text { Mean } \pm S D \\
\text { Range }\end{array}$ & $\begin{array}{l}3.78 \pm 0.29 \\
3.3-4.2\end{array}$ & $\begin{array}{l}3.80 \pm 0.49 \\
3-4.5\end{array}$ & 0.025 & 0.876 \\
\hline ALP (U/L) & $\begin{array}{l}\text { Mean } \pm S D \\
\text { Range }\end{array}$ & $\begin{array}{l}100.20 \pm 48.16 \\
50-189\end{array}$ & $\begin{array}{l}102.25 \pm 36.10 \\
51-165\end{array}$ & 0.023 & 0.880 \\
\hline Calcium (mg/dl) & $\begin{array}{l}\text { Mean } \pm S D \\
\text { Range }\end{array}$ & $\begin{array}{l}9.11 \pm 0.54 \\
8.4-10.4\end{array}$ & $\begin{array}{l}8.46 \pm 0.88 \\
6.3-9.7\end{array}$ & 1.797 & 0.207 \\
\hline Phosphorus (mg/ml) & $\begin{array}{l}\text { Mean } \pm S D \\
\text { Range }\end{array}$ & $\begin{array}{l}3.99 \pm 1.46 \\
0.9-6.5\end{array}$ & $\begin{array}{l}3.64 \pm 1.32 \\
1.1-6\end{array}$ & 0.809 & 0.424 \\
\hline PTH (pg/ml) & $\begin{array}{l}\text { Median (IQR) } \\
\text { Range }\end{array}$ & $\begin{array}{l}343(534) \\
46-1727\end{array}$ & $\begin{array}{l}297(608) \\
45-1080\end{array}$ & $z=0.049$ & 0.825 \\
\hline BALP (ng/ml) & $\begin{array}{l}\text { Mean } \pm \text { SD } \\
\text { Median (IQR) } \\
\text { Range }\end{array}$ & $\begin{array}{l}10.22 \pm 6.28 \\
12(16.32) \\
5-24\end{array}$ & $\begin{array}{l}11.64 \pm 6.34 \\
16.88(10.31) \\
5-24\end{array}$ & 0.505 & 0.482 \\
\hline
\end{tabular}

$t$ independent sample $t$-test, $X^{2}$ Chi-square test, $z$ Mann-Whitney test, IQR interquartile range, $P$-value $>0.05$ is considered significant (less than or equal 0.05 is significant) NS, BMI body mass index, SPBT short performance battery test, $A L P$ alkaline phosphatase, $P T H$ parathyroid hormone, BALP bone-specific alkaline phosphatase 
Table 2 Effect of exercise on short performance battery test and its components

\begin{tabular}{llllll}
\hline $\begin{array}{l}\text { Exercise group } \\
\boldsymbol{N}=\mathbf{2 0}\end{array}$ & Before & After & Mean Diff. & $\boldsymbol{t}$-test & $\boldsymbol{P}$-value \\
\hline Balance test & $1.15 \pm 0.37$ & $1.60 \pm 0.50$ & $0.45 \pm 0.51$ & -3.943 & $<0.001^{* *}$ \\
Gait speed test & $2.70 \pm 0.80$ & $2.95 \pm 0.69$ & $0.25 \pm 0.55$ & -2.032 & $0.046^{*}$ \\
Chair stand test & $2.55 \pm 0.51$ & $3.25 \pm 0.64$ & $0.70 \pm 0.80$ & -3.907 & $<0.001^{* *}$ \\
Total score & $6.40 \pm 1.05$ & $7.80 \pm 1.06$ & $1.40 \pm 0.99$ & -6.294 & $<0.001^{* *}$
\end{tabular}

$t$ paired sample $t$-test; $P$-value $>0.05$ is considered significant (less than or equal 0.05 is significant) NS

${ }^{*} P$-value $\leq 0.05 \mathrm{~S}$; ${ }^{* *} P$-value $\leq 0.001 \mathrm{v}$ HS

Bone profile showed favorable outcome in exercise group following completion of 3 months exercise. Parathormone level decreased significantly post-exercise from median (IQR) of 343 (534) to 231 (379) pg/ml, $P=$ 0.01 . Also, mean serum ALP levels increased from $100.20 \pm 48.16$ at baseline to $111.35 \pm 33.84$ IU/L postexercise $(P<0.05)$. Serum BALP very highly significantly increased from $10.22 \pm 6.28$ at baseline to $14.54 \pm 3.59 \mathrm{ng} /$ $\mathrm{ml}$ post exercise $(P<0.001)$. However, no similar change was detected in controls. Serum levels of $\mathrm{Ca}$ and $\mathrm{P}$ showed no significant difference from baseline in both groups as seen in Tables 3 and 4 .

In this work, a significant positive correlation was detected between short performance battery test scores and serum levels of BALP and ALP levels ( $r=$ 0.432, $P=0.01$ and $r=-0.503, P=0.01$ respectively). Also, a significant negative correlation between SPBT and serum PTH levels post-exercise $(r=-0.503, P=0.01)$ as seen in Table 5.

\section{Discussion}

Renal Association has recently set clinical practice guidelines for hemodialysis (HD) recommending that intradialytic exercise (IDE) should be available in all units, as a treatment for enhancing physical function in patients without contraindications [13].

Functional capacity should be measured and followed up in dialysis patients. According to Nogueira et al., owing to the busy schedule in HD unit and for practicality, short physical performance battery test (SPBT), sit stand test, timed up and go tests, and 6-min walk test are the most widely used for functional assessment in these patients [14]. Six-min walk test mean values in the exercise and control group in this study was comparable to that measured by Manfredini et al. in dialysis patients $328 \pm 96 \mathrm{~m}$ [15]. Renal failure is a significant negative predictor of performance at 6-min walk test [16]. For follow-up of functional capacity of patients, we used SPBT, which has the advantage of being quick, easy to complete for heterogenous group of patients, and useful for monitoring change. Variation of at least 1 point in SPBT score has clinical significance [14, 17]. The SPBT total score and all its components including gait speed, balance, and chair stand test significantly increased in the exercise group at follow-up $(P<0.05, P<0.001, P<$ $0.05, P<0.001$ respectively). However, controls showed no similar change. Previous studies revealed the positive effect of exercise on physical performance, functional capacity, and quality of life in HD patients $[18,19-21$

In the present study, mean hemoglobin level of patients in exercise and control group were comparable at

Table 3 Comparison between exercise and control group regarding physical performance scores and laboratory tests after 3 months follow-up

\begin{tabular}{|c|c|c|c|c|c|}
\hline & Groups & Exercise $\mathrm{Gr}(n=20)$ & Control $\mathrm{Gr}(n=20)$ & $\begin{array}{l}\text { Test } \\
t \text {-test }\end{array}$ & $P$-value \\
\hline SPBT & $\begin{array}{l}\text { Mean } \pm S D \\
\text { Range }\end{array}$ & $\begin{array}{l}7.80 \pm 1.06 \\
6-10\end{array}$ & $\begin{array}{l}6.10 \pm 0.97 \\
5-8\end{array}$ & 5.307 & $<0.001^{* *}$ \\
\hline HGB (g/dl) & $\begin{array}{l}\text { Mean } \pm S D \\
\text { Range }\end{array}$ & $\begin{array}{l}11.43 \pm 1.29 \\
9.7-13.8\end{array}$ & $\begin{array}{l}10.94 \pm 1.39 \\
9.8-12.6\end{array}$ & 1.169 & 0.250 \\
\hline Albumin (g/dl) & $\begin{array}{l}\text { Mean } \pm S D \\
\text { Range }\end{array}$ & $\begin{array}{l}4.58 \pm 0.46 \\
3.7-5.3\end{array}$ & $\begin{array}{l}3.97 \pm 0.35 \\
3.4-4.6\end{array}$ & 9.292 & $<0.001^{* *}$ \\
\hline ALP (U/L) & $\begin{array}{l}\text { Mean } \pm \text { SD } \\
\text { Range }\end{array}$ & $\begin{array}{l}111.35 \pm 33.84 \\
56-177\end{array}$ & $\begin{array}{l}107.90 \pm 35.28 \\
62-180\end{array}$ & 2.100 & $0.046^{*}$ \\
\hline CALCIUM (mg/dl) & $\begin{array}{l}\text { Mean } \pm S D \\
\text { Range }\end{array}$ & $\begin{array}{l}9.20 \pm 0.57 \\
8.1-10.3\end{array}$ & $\begin{array}{l}8.58 \pm 0.74 \\
7.4-9.9\end{array}$ & 1.817 & 0.205 \\
\hline Phosphorus (mg/ml) & $\begin{array}{l}\text { Mean } \pm S D \\
\text { Range }\end{array}$ & $\begin{array}{l}4.09 \pm 1.20 \\
2.3-6.6\end{array}$ & $\begin{array}{l}3.98 \pm 1.21 \\
1.6-6.3\end{array}$ & 0.302 & 0.765 \\
\hline PTH (pg/ml) & $\begin{array}{l}\text { Median (IQR) } \\
\text { Range }\end{array}$ & $\begin{array}{l}231(379) \\
45-1200\end{array}$ & $\begin{array}{l}292(599) \\
39-880\end{array}$ & $Z=2.712$ & $0.037^{*}$ \\
\hline BALP (ng/ml) & $\begin{array}{l}\text { Mean } \pm S D \\
\text { Range }\end{array}$ & $\begin{array}{l}14.54 \pm 3.59 \\
9.45-22.75\end{array}$ & $\begin{array}{l}12.20 \pm 7.01 \\
5-24\end{array}$ & $Z=2.571$ & $0.035^{*}$ \\
\hline
\end{tabular}

$t$ independent $t$-test, $z$ Mann-Whitney test, $P$-value $>0.05$ is considered significant (less than or equal 0.05 is significant) NS, IQR interquartile range, SPBT short performance battery test, $A L P$ alkaline phosphatase, $P T H$ parathyroid hormone, $B A L P$ bone-specific alkaline phosphatase

${ }^{*} P$-value $\leq 0.05 \mathrm{~S} ;{ }^{* *} P$-value $\leq 0.001$ 
Table 4 Change in physical performance and laboratory data in the exercise group and control group after 3 months follow-up

\begin{tabular}{|c|c|c|c|c|c|c|}
\hline & \multicolumn{3}{|l|}{ Exercise group $(n=20)$} & \multicolumn{3}{|l|}{$\begin{array}{l}\text { Control group } \\
(n=20)\end{array}$} \\
\hline & Mean difference \pm SD & $t$-test & $P$-value & Mean difference $\pm S D$ & $t$-test & $P$-value \\
\hline SPBT & $1.40 \pm 0.99$ & -6.294 & $<0.001^{* *}$ & $-0.45 \pm 0.83$ & 1.764 & 0.082 \\
\hline $\mathrm{HB}(\mathrm{mg} / \mathrm{dl})$ & $0.17 \pm 1.46$ & -0.522 & 0.608 & $-0.33 \pm 1.55$ & 0.938 & 0.360 \\
\hline Albumin (g/dl) & $0.80 \pm 0.57$ & -2.136 & $<0.001^{* *}$ & $0.17 \pm 0.30$ & -1.046 & 0.308 \\
\hline ALP (U/L) & $11.15 \pm 20.51$ & -0.369 & $0.025^{*}$ & $5.65 \pm 6.66$ & 1.122 & 0.276 \\
\hline CALCIUM (mg/dl) & $0.09 \pm 0.38$ & 6.304 & $0.024^{*}$ & $0.12 \pm 0.39$ & -1.841 & 0.129 \\
\hline Phosphorus (mg/ml) & $0.10 \pm 0.74$ & 2.431 & 0.552 & $0.34 \pm 0.58$ & -1.147 & 0.224 \\
\hline PTH (pg/ml) & $-27.70 \pm 59.76$ & 2.331 & $0.011^{*}$ & $8.25 \pm 102.55$ & -1.376 & 0.185 \\
\hline BALP (ng/ml) & $4.32 \pm 3.20$ & -0.606 & $<0.001^{* *}$ & $0.56 \pm 1.77$ & -1.503 & 0.182 \\
\hline
\end{tabular}

baseline and follow-up. This was in agreement with Afshar et al. who found that aerobic exercise in HD patients had no influence on hemoglobin levels [22]. However, in the work by Assawasaksakul et al., IDE improved hemoglobin levels in patients [20]. Also, regarding serum albumin levels at baseline, no difference was detected between groups, but its levels increased significantly in the exercise group after 3 months $(P<$ $0.05)$ with no similar change in the controls. Previous work showed significant increase in serum albumin (g/ dL) following aerobic exercise in dialysis patients [21]. This could be attributed to effect of exercise in helping to decrease infection, reducing inflammatory markers, and improving nutritional and psychological status in hemodialysis patients [23]. However, others found exercise had no influence on serum albumin level in dialysis patients [22].

As regards bone markers, there was no difference between both groups regarding serum levels of PTH, ALP, BSAP, calcium, and phosphorus at baseline. At followup, PTH levels decreased significantly in exercise group $P=0.01$. However, controls showed no similar change. According to KDIGO guidelines [4], maintenance of serum PTH levels in dialysis patients within a range of 2 to 9 times the upper limit of normal range of the assay is recommended, but the lowest risk of mortality was observed with a PTH of $398 \mathrm{pg} / \mathrm{ml}$ [24]. In end-stage renal disease (ESRD), there is a tendency for PTH to

Table 5 Showing the relation between physical performance and serum levels of ALP, BALP, and PTH post-exercise

\begin{tabular}{|c|c|c|c|c|c|c|}
\hline & \multicolumn{2}{|c|}{ ALP (u/l) } & \multicolumn{2}{|c|}{ PTH (pg/ml) } & \multicolumn{2}{|c|}{ BALP (ng/ml) } \\
\hline & $r$ & $P$-value & $r$ & $P$-value & $r$ & $P$-value \\
\hline SPBT & 0.645 & $0.006^{*}$ & -0.503 & $0.012^{*}$ & 0.432 & $0.013^{*}$ \\
\hline
\end{tabular}

$r$ Spearman's rank correlation coefficient, $P$-value $>0.05 \mathrm{NS}, S P B T$ short performance battery test, $H B$ hemoglobin, $A L P$ alkaline phosphatase, $P T H$ parathyroid hormone, BALP bone-specific alkaline phosphatase ${ }^{*} P$-value $\leq 0.05 \mathrm{~S}$ increase reflecting increased bone turnover in these patients [25]. Parathormone inhibits the production of osteoprotegerin and stimulates the expression of bone nuclear factor kappa-B ligand on osteoblasts favoring bone resorption [26]. Research on effect of exercise on PTH is limited, but it is affected by physical activity. Its levels can vary after physical exercise depending on the duration and intensity of the activity. It has been shown to increase with acute and decrease with chronic exercise especially in sedentary population [27]. Previous work showed that exercise decreased plasma PTH levels in CKD patients [28]. The fact that it decreased with exercise showed favorable effect of exercise on bone metabolism helpful for maintaining bone quality. However, bone turnover is very slow, and PTH secretion is quickly influenced by level of serum-ionized calcium. Moreover, resistance to $\mathrm{PTH}$ action can occur with progression of renal disease [27].

Alkaline phosphatases (ALP) are glycoproteins produced in different organs. In CKD, ALP is more reliable than many other biochemical bone markers because serum concentrations of ALP are not influenced by the glomerular filtration rate (GFR) [29]. Bone-specific alkaline phosphatase (BALP) is released from osteoblasts and plays a major role in bone mineralization. In studies of bone histology, BALP showed higher significant correlation with bone formation than total ALP [30]. Also, it showed higher sensitivity and specificity for bone turnover compared to PTH [31]. In this work, mean serum ALP levels significantly increased in exercise group, but controls showed no similar change on follow-up. Previous study by Gomes et al. showed there was significant increase in ALP levels following 24 weeks of aerobic exercise in patients with CKD despite no observed changes in other bone markers [32]. Serum BALP level in the present work also increased significantly in the exercise group on follow-up $(P<0.001)$. The controls showed no 
similar change. Previous studies on osteoporotic patients revealed increased serum levels of BALP following exercise [33]. This implies that the osteogenic stimuli triggered by exercise may have an important impact on bone formation in HD patients.

In the present work, serum calcium and phosphorus levels showed no change in either group at follow-up. Salhab et al. also failed to retrieve in their systemic review any influence of exercise on serum phosphorus [34]. However, previous studies revealed that IDE exercise programs reversed hyperphosphatemia commonly seen among HD patients [20,35]. Perhaps, more studies with larger number of participants and longer time frame are needed.

Physical performance using SPBT in the present work showed an inverse correlation with serum PTH levels and positive significant correlation with both ALP and BALP levels in exercise group following 3 months of cycling exercise implying that improvement in physical performance was associated with bone formation and decreased bone resorption. Cardoso et al. in their systemic review found evidence supporting a positive relation between physical activity and bone outcomes in patients with CKD [8]. Previous studies recommended the implementation of resistance exercise for improving bone mass because of osteogenic effect induced due to mechanical load $[7,8,36]$. However, in ESRD sedentary patients, not enrolled in any previous exercise routine, cycling could have provided load enough on muscles, exceeding levels of activities of daily living and inducing an osteogenic stimulus. Further prolonged studies in HD patients comparing aerobic, resistance, and combined exercise are recommended.

\section{Conclusion}

Intradialytic exercise resulted in improvement in physical performance, decreased serum PTH level, and increased serum ALP and BSAP levels in HD patients. Aerobic exercise has a favorable outcome, not only on physical performance but also on bone metabolism in HD patient.

\section{Limitation of the study}

The limitations of this study included the small number of patients, short duration of follow up and not measuring the effect of exercise on bone mass. Indeed, not measuring bone mineral density in this work is a limitation as bone strength depends on bone quality and quantity, but it would have required longer period of follow-up to 6 months or more for changes to be observed. Future work should focus on observing the effect of different types of exercise on bone mass in HD patients, with bone turnover markers as primary endpoints because of their ease and practicality of measurement in the busy HD unit environment.

\begin{abstract}
Abbreviations
ALP: Alkaline phosphatase; BALP: Bone-specific alkaline phosphatase; BMI: Body mass index; CKD: Chronic kidney disease; CKD-MBD: Chronic kidney disease mineral and bone disorder; ESRD: End-stage renal disease; HD: Hemodialysis; IDE: Intradialytic exercise; KDIGO: Kidney Disease: Improving Global Outcomes; LBM: Lean body mass; MBD: Mineral and bone disorder; IQR: Interquartile range
\end{abstract}

\section{Acknowledgements \\ Not applicable}

\section{Authors' contributions}

HE: main idea, revised the paper; AM: collected clinical data, data analysis, wrote the paper; DF: study design, follow-up of patients, edited the paper; MA: clinical supervision, data analysis, edited the paper. All authors have read and approved the manuscript.

Funding

This study had no funding from any resource.

\section{Availability of data and materials}

The datasets used and/or analyzed during the current study are available from the corresponding author on reasonable request.

\section{Declarations}

\section{Ethics approval and consent to participate}

This study was approved by the Research Ethics Committee of the Faculty of Medicine at Ain Shams University in Egypt on 22 April 2020; Reference Number of approval: F285. All patients included in this study gave written informed consent to participate in this research. If the patient was less than 16 years old or unconscious at the time of the study, written informed consent for their participation was given by their parent or legal guardian. This paper has not been published or submitted for publication elsewhere.

\section{Consent for publication}

All patients included in this research gave written informed consent to publish the data contained within this study. If the patient was less than 16 years old, deceased, or unconscious when consent for publication was requested, written informed consent for the publication of this data was given by their parent or legal guardian.

\section{Competing interests}

The authors declare that they have no competing interests.

\section{Author details}

${ }^{1}$ Department of Internal Medicine \& Nephrology, Faculty of Medicine, Ain Shams University, Cairo, Egypt. ²Department of Physical Medicine, Rheumatology and Rehabilitation, Faculty of Medicine, Ain Shams University, Cairo, Egypt.

Received: 3 March 2021 Accepted: 8 April 2021

Published online: 06 May 2021

\section{References}

1. Moldovan D, Rusu C, Kacso IM, Potra A, Patiu IM, Gherman-Caprioara M (2016) Mineral and bone disorders, morbidity and mortality in end-stage renal failure patients on chronic dialysis. Clujul Med 89(1):94-103. https:// doi.org/10.15386/cjmed-515

2. Moe S, Drueke T, Cunningham J, Goodman W, Martin K, Olgaard K, Ott S, Sprague S, Lameire N, Eknoyan G et al (2006) Definition, evaluation, and classification of renal osteodystrophy: a position statement from Kidney Disease: Improving Global Outcomes (KDIGO). Kidney Int 69(11):1945-1953. https://doi.org/10.1038/sj.ki.5000414

3. Damasiewicz MJ, Nickolas TL (2018) Rethinking bone disease in kidney disease. JBMR Plus 2(6):309-322. https://doi.org/10.1002/jbm4.10117

4. Kidney Disease: Improving Global Outcomes (KDIGO) CKD-MBD Work Group (2017) KDIGO 2017 Clinical practice guideline update for the diagnosis, 
evaluation, prevention, and treatment of chronic kidney disease-mineral and bone disorder (CKD-MBD). Kidney Int Suppl 7:1-59

5. Lopes AA, Lantz B, Morgenstern H, Wang M, Bieber BA, Gillespie BW, Li Y, Painter P, Jacobson SH, Rayner HC, Mapes DL, Vanholder RC, Hasegawa T, Robinson BM, Pisoni RL (2014) Associations of self-reported physical activity types and levels with quality of life, depression symptoms, and mortality in hemodialysis patients: the DOPPS. Clin J Am Soc Nephrol 9(10):1702-1712. https://doi.org/10.2215/CJN.12371213

6. Mallamaci F, Pisano A, Tripepi G (2020) Physical activity in chronic kidney disease and the EXerCise introduction to enhance trial. Nephrol Dial Transplant 35(2):ii18-ii22. https://doi.org/10.1093/ndt/gfaa012

7. Benedetti MG, Furlini G, Zati A, Mauro GL (2018) The effectiveness of physical exercise on bone density in osteoporotic patients. Biomed Res Int ArticlelD4840531. https://doi.org/10.1155/2018/4840531

8. Cardoso DF, Marques EA, Leal DV, Ferreira A, Baker LA, Smith AC, Viana JL (2020) Impact of physical activity and exercise on bone health in patients with chronic kidney disease: a systematic review of observational and experimental studies. BMC Nephrol 21 (1):334. https://doi.org/10.1186/s12882-020-01999-z

9. ATS Committee on Proficiency Standards for Clinical Pulmonary Function Laboratories (2002) ATS statement: guidelines for the six-minute walk test. Am J Respir Crit Care Med 166(1):111-117. https://doi.org/10.1164/airccm.166.1.at1102

10. Guralnik JM, Simonsick EM, Ferrucci L, Glynn RJ, Berkman LF, Blazer DG, Scherr PA, Wallace RB (1994) A short physical performance battery assessing lower extremity function: association with self-reported disability and prediction of mortality and nursing home admission. J Gerontol 49(2):M85M94. https://doi.org/10.1093/geronj/49.2.M85

11. Parker K (2016) Intradialytic exercise is medicine for hemodialysis patients. Curr Sports Med Rep 15(4):269-275

12. Borg GA (1982) Psychophysical bases of perceived exertion. Med Sci Sports Exerc 14(5):377-381

13. Ashby D, Borman N, Burton J, Corbett R, Davenport A, Farrington K, Flowers K, Fotheringham J, Andrea Fox RN, Franklin G, Gardiner C, Martin Gerrish RN, Greenwood S, Hothi D, Khares A, Koufaki P, Levy J, Lindley E, Macdonald J, Mafrici B, Mooney A, Tattersall J, Tyerman K, Villar E, Wilkie M (2019) Renal association clinical practice guideline on haemodialysis. BMC Nephrol 20(1): 379. https://doi.org/10.1186/s12882-019-1527-3

14. Nogueira A, Álvarez G, Russo F, San-José B, Sánchez-Tomero JA, Barril G (2019) Is SPPB useful as a method for screening functional capacity in patients with advanced chronic kidney disease? Nefrología 39(5):489-496. https://doi.org/10.1016/j.nefroe.2019.01.010

15. Manfredini F, Mallamaci F, D'Arrigo G, Baggetta R, Bolignano D, Torino C, Lamberti N, Bertoli S, Ciurlino D, Rocca-Rey L, Barillà A, Battaglia Y, Rapanà RM, Zuccalà A, Bonanno G, Fatuzzo P, Rapisarda F, Rastelli S, Fabrizi F, Messa P, de Paola L, Lombardi L, Cupisti A, Fuiano G, Lucisano G, Summaria C, Felisatti M, Pozzato E, Malagoni AM, Castellino P, Aucella F, Abd ElHafeez S, Provenzano PF, Tripepi G, Catizone L, Zoccali C (2017) Exercise in patients on dialysis: a multicenter, randomized clinical trial. J Am Soc Nephrol 28(4): 1259-1268. https://doi.org/10.1681/ASN.2016030378

16. Bučar Pajek M, Čuk I, Leskošek B, Mlinšek G, Buturović Ponikvar J, Pajek J (2016) Six-minute walk test in renal failure patients: representative results, performance analysis and perceived dyspnea predictors. PLoS One 11(3): e0150414. https://doi.org/10.1371/journal.pone.0150414

17. Perera S, Mody SH, Woodman RC, Studenski SA (2006) Meaningful change and responsiveness in common physical performance measures in older adults. J Am Geriatr Soc 54(5):743-749. https://doi.org/10.1111/j.1532-5415

18. Abou El-Saoud A, Shehata O, Emerah A, Sayed E (2014) Evaluation of exercise training on work capacity, functional mobility and quality of life in hemodialysis patients. Egypt Rheumatol Rehabil 41(3):103-108. https://doi. org/10.4103/1110-161X.140524

19. Lopes LCC, Mota JF, Prestes J, Schincaglia RM, Silva DM, Queiroz NP, Freitas AT, Lira FS, Peixoto MD (2019) Intradialytic resistance training improves functional capacity and lean mass gain in individuals on hemodialysis: a randomized pilot trial. Arch Phys Med Rehabil 100(11):2151-2158. https:// doi.org/10.1016/.j.apmr.2019.06.006

20. Assawasaksakul N, Sirichana W, Joosri W, Kulaputana O, Eksakulkla S, Ketanun C, Kittiskulnam P, Chantadisai M, Takkavatakarn K, Susantitaphong P, Praditpornsilpa K, Eiam-Ong S, Tiranathanagul K (2021) Effects of intradialytic cycling exercise on daily physical activity, physical fitness, body composition, and clinical parameters in high-volume online hemodiafiltration patients: a pilot randomized-controlled trial. Int Urol Nephrol 53(2):359-371. https://doi.org/10.1007/s11255-020-02677-7
21. Kopple JD, Wang H, Casaburi R, Fournier M, Lewis MI, Taylor W, Storer TW (2007) Exercise in maintenance hemodialysis patients induces transcriptional changes in genes favoring anabolic muscle. JASN 18(11):2975-2986. https:// doi.org/10.1681/ASN.2006070794

22. Afshar R, Shegarfy L, Shavandi N, Sanavi S (2010) Effects of aerobic exercise and resistance training on lipid profiles and inflammation status in patients on maintenance hemodialysis. Indian J Nephrol 20(4):185-189. https://doi. org/10.4103/0971-4065.73442

23. Dong ZJ, Zhang HL, Yin LX (2019) Effects of intradialytic resistance exercise on systemic inflammation in maintenance hemodialysis patients with sarcopenia: a randomized controlled trial. Int Urol Nephrol 51(8):1415-1424. https://doi.org/10.1007/s11255-019-02200-7

24. Fernandez-Martin JL et al (2015) Improvement of mineral and bone metabolism markers is associated with better survival in hemodialysis patients: the COSMOS study. Nephrol Dial Transplant 30(9):1542-1551. https://doi.org/10.1093/ndt/gfv099

25. Cannata-Andía JB, Martín-Carro B, Martín-Vírgala J, Rodríguez-Carrio J, Bande-Fernández JJ, Alonso-Montes C, Carrillo-López N (2020) Chronic kidney disease - mineral and bone disorders: pathogenesis and management. Calcif Tissue Int. https://doi.org/10.1007/s00223-020-00777-1

26. Ma YL, Cain RL, Halladay DL, Yang X, Zeng Q, Miles RR, Chandrasekhar S, Martin TJ, Onyia JE (2001) Catabolic effects of continuous human PTH (1-38) in vivo is associated with sustained stimulation of RANKL and inhibition of osteoprotegerin and gene-associated bone formation. Endocrinology. 142(9):4047-4054. https://doi.org/10.1210/endo.142.9.8356

27. Lombardi G, Ziemann E, Banfi G, Corbetta S (2020) Physical activitydependent regulation of parathyroid hormone and calcium-phosphorous metabolism. Int J Mol Sci 21(15):5388. https://doi.org/10.3390/ijms21155388

28. Bouassida A, Latiri I, Bouassida S, Zalleg D, Zaouali M, Feki Y, Gharbi N, Zbidi A, Tabka Z (2006) Parathyroid hormone and physical exercise: a brief review. J Sports Sci Med 5(3):367-374

29. Sardiwal S, Gardham C, Coleman AE, Stevens PE, Delaney MP, Lamb EJ (2012) Bone specific alkaline phosphatase concentrations are less variable than those of parathyroid hormone in stable hemodialysis patients. Kidney Int 82(1):100-105. https://doi.org/10.1038/ki.2012.77

30. Sprague SM, Bellorin-Font E, Jorgetti V, Carvalho AB, Malluche HH, Ferreira A, D'Haese PC, Drüeke TB, Du H, Manley T, Rojas E, Moe SM (2016) Diagnostic accuracy of bone turnover markers and bone histology in patients with CKD treated by dialysis. Am J Kidney Dis 67(4):559-566. https://doi.org/10.1053/j.ajkd.2015.06.023

31. Cavalier E (2018) Bone markers and chronic kidney diseases. J Lab Prec Med 3:62. https://doi.org/10.21037/jpm.2018.07.03

32. Gomes TS, Aioke DT, Baria FG, Graciolli FG, Moyses RMA, Cuppari L (2017) Effect of aerobic exercise on markers of bone metabolism of overweight and obese patients with chronic kidney disease. J Ren Nutr 27(5):364-371. https://doi.org/10.1053/j.jrn.2017.04.009

33. Marini S, Barone G, Masini A, Dallolio L, Bragonzoni L, Longobucco Y, Maffei F (2020) The effect of physical activity on bone biomarkers in people with osteoporosis: a systematic review. Front Endocrinol 11:837. https://doi.org/1 0.3389/fendo.2020.585689

34. Salhab N, Alrukhaimi M, Kooman J, Fiaccadori E, Aljubori H, Rizk R, Karavetian M (2019) Effect of intradialytic exercise on hyperphosphatemia and malnutrition. Nutrients 11(10):2464. https://doi.org/10.3390/nu11102464

35. Musavian AS, Soleimani A, Masoudi Alavi N, Baseri A, Savari F (2015) Comparing the effects of active and passive intradialytic pedaling exercises on dialysis efficacy, electrolytes, hemoglobin, hematocrit, blood pressure and health-related quality of life. Nurs Midwifery Stud 4(1):e25922. https:// doi.org/10.17795/nmsjournal25922

36. Hong AR, Kim SW (2018) Effects of resistance exercise on bone health Endocrinol Metab 33(4):435-444. https://doi.org/10.3803/EnM.2018.33.4.435

\section{Publisher's Note}

Springer Nature remains neutral with regard to jurisdictional claims in published maps and institutional affiliations. 